Hematol Oncol Clin North Am. 2012 June ; 26(3): 629-ix. doi:10.1016/j.hoc.2012.02.002.

\title{
The Antifolates
}

\author{
Michele Visentin, Rongbao Zhao, and I. David Goldman* \\ Departments of Medicine, Molecular Pharmacology and the Albert Einstein Cancer Center. The \\ Albert Einstein College of Medicine, Bronx, NY 10803
}

\section{Keywords}

Methotrexate; pralatrexate; pemetrexed; antifolates; reduced folate carrier (RFC); proton-coupled folate transporter (PCFT); folate receptors; folate receptor-mediated endocytosis

\section{Introduction}

The antifolates were the first class of antimetabolites to enter the clinics 65 years ago. Their mechanism of action is due to the disruption of the metabolic pathways that require onecarbon moieties supplied by the B9 folate vitamins which they resemble. While renewing tissues of the bone marrow and intestinal tract are also folate-dependent and are sites of antifolate toxicity, the clinical utility of antifolates was established with the identification of doses and schedules of administration that provided sufficient selectivity to make these drugs effective in the treatment of cancer as well as inflammatory disorders. Many of the early key preclinical studies that defined the pharmacological properties of this class of drugs, and treatment strategies, were conducted in vitro and, in vivo in mice, using murine leukemia cell lines ${ }^{1,2}$.

The first antifolate in the clinic was aminopterin. Its introduction, as first reported in the New England Journal of Medicine in June $1948^{3}$, was greeted with great enthusiasm when this agent was shown to produce, for the first time, remissions in children with acute lymphoblastic leukemia. While these remissions were short-lived, the activity of this agent established that this disease was treatable and provided optimism that this and other malignant diseases would be conquerable with cancer chemotherapeutics in the future. For reasons not fully understood, but attributed to the unpredictable toxicity of aminopterin, this drug was replaced with methotrexate (MTX) in the early 1950s, an antifolate less potent that aminopterin but with what was considered to be a more favorable therapeutic index ${ }^{2}$.

Despite its early clinical success, an understanding of the mechanism of action of MTX evolved slowly over the ensuing decades. Likewise, the efficacy and selectivity of leucovorin "rescue" that allowed the safe administration of high doses of MTX was established entirely empirically and, even today, the basis for the selectivity of this regimen is not widely appreciated nor fully understood. The lack of a basic understanding of the biochemical and molecular pharmacology of MTX hampered efforts to develop subsequent generations of antifolates that would lead to the realization of the full clinical potential of

(C) 2012 Elsevier Inc. All rights reserved.

*Corresponding author .

Publisher's Disclaimer: This is a PDF file of an unedited manuscript that has been accepted for publication. As a service to our customers we are providing this early version of the manuscript. The manuscript will undergo copyediting, typesetting, and review of the resulting proof before it is published in its final citable form. Please note that during the production process errors may be discovered which could affect the content, and all legal disclaimers that apply to the journal pertain. 
this class of drugs. Hence, it was more than fifty years after the introduction of MTX that the second antifolate, pemetrexed, was approved in 2004 for the treatment of mesothelioma and subsequently non-small cell lung cancer. This was followed by approval of pralatrexate in 2009 for the treatment of cutaneous T-cell lymphoma.

This chapter will focus on the cellular, biochemical, and molecular pharmacology of antifolates and how a basic understanding of the mechanism of action of MTX, its cytotoxic determinants, mechanisms of resistance, and transport into and out of cells, has led to the development of a new generations of antifolates, a process that continues both in the laboratory and in the clinics. Finally, new approaches to folate-based cancer chemotherapy will be described based upon targeted delivery of drugs to malignant cells. These include, (i) the development of folate analogues transported by routes selectively expressed and/or active in tumor cells and (ii) the selective endocytosis of folic acid, linked to cytotoxics, into tumor cells that express folate receptors. The evolution of antifolates, folate receptor targeted drugs, and membrane transport of folates and antifolates have been the subject of recent reviews ${ }^{4-11}$

\section{Antifolates Achieve their Pharmacological Effects by their Perturbations of Folate Metabolism}

The structures of the B9 vitamins in their oxidized (folic acid) and reduced forms are illustrated in figure 1. Folic acid is not a physiological folate but is an important source of folates ingested because it is added as a supplement to foods and it is the predominant form of folate in vitamin supplements. The major dietary folate in nature, 5methyltetrahydrofolate (5-methylTHF), is absorbed in the proximal small intestine by a highly specific transport mechanism, the proton-coupled folate transporter (PCFT-see below) following which it is delivered to the liver via the hepatic portal vein ${ }^{6,12}$. There, large amounts of 5-methylTHF accumulate as polyglutamate derivatives (see below). Following conversion back to the monoglutamate form, this folate exits hepatic cells to circulate in the blood for delivery via the reduced folate carrier (RFC -see below) to peripheral tissues. There it provides its methyl group to homocysteine for the synthesis of methionine with the generation of a tetrahydrofolate moiety in a vitamin B-12 requiring reaction mediated by the enzyme methionine synthase (Figure 2). The tetrahydrofolate generated then proceeds, through a variety of reactions, to acquire another carbon at various oxidation states at the $\mathrm{N}^{5}, \mathrm{~N}^{10}$, or shared between both positions, to form a family of tetrahydrofolate cofactors. These one-carbon derivatives sustain key biosynthetic reactions within cells such as the addition of a single carbon in the synthesis of thymidylate and two carbons in the synthesis of purines - both required for the synthesis of DNA and RNA. Methionine goes on to form S-adenosyl methionine which then mediates a variety of methylation reactions including the methylation of cytosines within DNA a key factor in the regulation of transcription and activities of oncogenes and tumor suppressor genes ${ }^{13}$. In the absence of vitamin B12, the utilization of 5-methylTHF cannot occur, 5-methylTHF is "trapped" so that neither its one-carbon nor tetrahydrofolate moieties are available for biosynthetic reactions ${ }^{14}$. Proliferating tissues, with a high requirement for folates, are the most susceptible to folate deficiency and to drugs that block these folate-dependent pathways.

In the synthesis of methionine and purines, the tetrahydrofolate molecule remains intact and another carbon moiety can be acquired to be utilized again in one-carbon reactions (Figure 2). However, in the synthesis of thymidylate from deoxuridylate that requires 5,10 methylene tetrahydrofolate (5,10-methyleneTHF), tetrahydrofolate is oxidized to dihydrofolate. In proliferating cells this reaction is so rapid that tetrahydrofolate cofactors would rapidly interconvert to 5,10-methyleneTHF, followed by oxidization to dihydrofolate, 
in minutes if it were not for the enzyme, dihydrofolate reductase (DHFR) which rapidly reduces dihydrofolate back to tetrahydrofolate to sustain the pool of tetrahydrofolate cofactors.

Figure 3 illustrates the structures of aminopterin and MTX. The former differs from folic acid only in the substitution of an amino for a hydroxyl group at the $\mathrm{N}^{4}$-position of the pteridine ring. MTX differs from aminopterin in having the addition of a methyl group at the $\mathrm{N}^{10}$ position, in a bridge between the pteridine and p-amino-benzoic acid moieties. These structural differences from folic acid confer on these analogs an extremely high affinity for DHFR. The primary action of aminopterin and methotrexate (MTX), the "classical" antifolates, is the inhibition of this enzyme. The 4-amino antifolates are among the most potent enzyme inhibitors known. When the interaction between the drug and its target enzyme is evaluated in cell-free systems, the inhibition constant is $\sim 5 \mathrm{pM}$. This is comparable to what can be achieved with inhibitors designed to bind within the transition state of the catalytic sites of enzymes ${ }^{15}$. However, micromolar levels of MTX are required to inhibit this enzyme within cells. There are two reasons for this discrepancy: (i) DHFR is present in cells in great excess so that inhibition of more than $95 \%$ of the enzyme is required to begin to suppress tetrahydrofolate synthesis and (ii) as illustrated in Figure 4, the substrate for this reaction, dihydrofolate, builds to high levels behind the block as tetrahydrofolate cofactors interconvert and cycle to 5,10-methyleneTHF which is oxidized via thymidylate synthase. Dihydrofolate levels become so high that they compete with MTX for the small percentage of enzyme that is sufficient to support tetrahydrofolate synthesis. To overcome this inhibition and achieve saturation of the enzyme requires relatively high, micromolar, intracellular levels of MTX. Indeed, if after sufficient levels of MTX are present within the cell to completely block this reaction, cells are placed in a MTX-free environment, the drug rapidly leaves the cell, a small component of MTX bound to DHFR is displaced by the high levels of dihydrofolate, tetrahydrofolate synthesis resumes, tetrahydrofolate cofactors rapidly increase to normal levels, and dihydrofolate decreases to its usual very low levels leaving $>95 \%$ of the enzyme still associated with MTX. This is the sequence of events that occurs within cancer cells as MTX blood levels rise and fall after administration of the drug. Hence, a very potent inhibitor of DHFR in a cell-free system is a competitive and rapidly reversible inhibitor when interacting with its target enzyme within the dynamic environment of the cell where pools of substrate and products can undergo large changes when enzyme activities are perturbed ${ }^{16}$.

Based upon this understanding of the critical elements of MTX interactions within cells, it becomes clear that a major determinant of the activity of this agent is the intracellular level achieved. There are two determinants of the cell antifolate level: (i) membrane transport and, (ii) metabolic conversion to derivatives that remain potent inhibitors of DHFR but are retained within the cell and accumulate to high levels.

\section{Pharmacological Consequences of the Formation of Methotrexate Polyglutamate Derivatives within Cells}

Physiological folates form polyglutamate derivatives that are retained and build to high levels within cells. These are usually preferred substrates for tetrahydrofolate cofactorrequiring enzymes ${ }^{17,18}$. In a series of reactions, mediated by folylpolyglutamate synthetase (FPGS), glutamate molecules are added successively at the $\mathrm{\gamma}$-carboxyl moiety to form a peptide chain of up to six to eight glutamate residues. Antifolates undergo the same reaction and this has profound pharmacological ramifications. The polyglutamation of antifolates, (as seen for MTX in Figure 5), converts these drugs from a form (monoglutamate) that is a good substrates for a variety of folate export processes, to forms that are not, leading to the retention and build-up of high levels of polyglutamate derivatives in tumor cells. In the case 
of MTX these derivatives are at least as potent inhibitors of DHFR as the monoglutate. The retention of MTX polyglutamate derivatives within cells, after antifolate blood levels fall, results in sustained inhibition of this enzyme for long intervals. In the case of pemetrexed, polyglutamation results in derivatives with a much higher affinity for its target enzymes than the monoglutamate and this, along with prolonged retention in tumor cells, allows regimens in which this agent can be administered every three weeks (see below).

A key factor in the efficacy of any antineoplastic agent is its selectivity - the extent to which it kills malignant cells while sparing susceptible host tissues. In the case of MTX, the major toxicities are due to its effects on intestinal and bone marrow cells. The basis for this selectivity appears to be due, at least in part, to the lesser accumulation of its polyglutamate derivatives in these normal replicating tissues in comparison to susceptible tumor cells 19-22. Hence, when the drug is administered intravenously in a pulse, MTX is transported into tumor cells where polyglutamate derivatives are synthesized and accumulate. When the concentration of MTX in the blood falls below a critical level, formation of polyglutamates cease but the polyglutamate derivatives already synthesized are retained and produce prolonged suppression of DHFR. On the other hand, while MTX monoglutamate builds within intestinal and bone marrow cells when the concentration of MTX in the blood is high, as the MTX blood level falls, MTX monoglutamate exits the cells and, in the absence of polyglutamate derivatives, the very small component of DHFR necessary to meet cellular demands for tetrahydrofolate is rapidly activated ${ }^{20-22}$. For a detailed analysis of the perturbations of cellular folate pools in response to 4-amino antifolates and the impact of the formation of poyglutamate derivatives, the reader is referred to an earlier review 16

\section{The Membrane Transport of Antifolates Mediated by Facilitative Carriers and Export Pumps}

The physiological folates as well as most antifolates are bivalent anions, hydrophilic compounds that diffuse poorly across cell membranes. Relatively low levels of folates are present in the diet and in the blood; hence, specific processes are required to achieve their efficient transport across epithelia and into systemic cells (Figure 6). Transport across the apical-brush border membrane of the duodenum and proximal jejunum is mediated by the proton-coupled folate transporter (PCFT) a process that functions optimally at the low-pH found at the microenvironment of the surface of the villi of these tissues. Its critical role in this process was established with the demonstration that there are loss of function mutations in this gene in the autosomal hereditary disorder, hereditary folate malabsorption ${ }^{12,23,24}$. PCFT is expressed in many normal tissues but because of the ambient neutral $\mathrm{pH}$, it has very limited function. Besides the proximal small intestine, PCFT is highly expressed in the liver, choroid plexus and the brush-border membrane of the proximal renal tubule and in a broad spectrum of solid tumors 25,26 . Transport into systemic tissues is mediated by the reduced folate carrier (RFC) a process that functions optimally at the neutral $\mathrm{pH}$ sustained in most tissues. RFC is expressed in all normal and malignant cells and is the major route of 5methylTHF transport into these tissues. RFC is also a major route of transport of MTX and most other antifolates into tumor cells ${ }^{7,26}$.

MTX, raltitrexed, and pemetrexed share comparable affinities for RFC, with influx $\mathrm{K}_{\mathrm{m}} \mathrm{s}$ of $~$ 5-7 $\mu \mathrm{M}$ at the optimal $\mathrm{pH}$ of this transporter - 7.4. The affinity of RFC for the natural isomer of 5-methylTHF is greater. The affinity of RFC for pralatrexate is 3-4 times greater than for MTX. The affinities and maximum transport velocities mediated by PCFT are highest at $\mathrm{pH} \sim 5.5$ and decrease as the $\mathrm{pH}$ is increased. At its optimal low $\mathrm{pH}$, the affinity of PCFT is greatest for pemetrexed $\left(\mathrm{K}_{\mathrm{m}} \sim 0.2-0.5 \mu \mathrm{M}\right)$ but still quite good for MTX $\left(\mathrm{K}_{\mathrm{m}} \sim 1.5\right.$ $\mu \mathrm{M})$. As the $\mathrm{pH}$ is increased transport is much better preserved for pemetrexed than MTX or raltitrexed 27,28 . 
Both RFC and PCFT are facilitative carriers that mediate folate and antifolate entry (influx) and exit (efflux) from cells. The extent to which these processes are unequal will determine the final concentration gradient achieved across the cell membrane. PCFT contains two substrates binding sites; one for a proton the other for a folate/antifolate. This symporter utilizes the transmembrane proton gradient to achieve concentrative folate transport into cells. RFC contains only one substrate binding site, for a folate/antifolate. However, a variety of structurally unrelated organic anions can compete for this site and can utilize this carrier; the most potent of which are the organic phosphates. This transporter utilizes the high concentration of organic phosphates within cells to achieve concentrative folate/ antifolate transport into cells. Hence, while both transporters are bidirectional and are capable of transporting folates/antifolates into and out of cells, export mediated by PCFT is suppressed by the neutral $\mathrm{pH}$ within the intracellular compartment. Likewise, export mediated by RFC, an antiporter, is suppressed by the high levels of organic phosphates within cells. These assymetrical effects by protons and organic phosphates, respectively, result in concentrative (uphill) folate/antifolate transport into cells.

Antifolates are also substrates for members of the family of multidrug resistance associated proteins, MRPs and the breast cancer-resistance protein (BCRP) ${ }^{29-31}$. These ATP-

dependent exporters oppose the concentrative effects of RFC or PCFT to suppress the level of monoglutamate antifolates that accumulate within cells and thereby slow the formation of polyglutamate derivatives. When these exporters are inhibited, intracellular MTX levels increase. Once polyglutamate derivatives form they are no longer substrates for most of these exporters. However, the lower polyglutamate derivatives of MTX are modest substrates for some MRPs and BCRP ${ }^{29,30}$. The level of monoglutamyl antifolates that accumulate within cells is determined by the net effect of the exporters and the carrier mediated concentrative transporters. Cumulatively, these factors influence the rate and extent of accumulation of antifolate polyglutamate derivatives within cells. While overexpression of MRPs and BCRP can induce resistance to antifolates, it is unclear as to whether this contributes to resistance to these agents in the clinics ${ }^{31}$.

Membrane transport of methotrexate mediated by RFC is an important determinant of its cytotoxicity. The higher the affinity of RFC for this drug, the higher the free levels achieved within the intracellular water and the greater the rate and extent of formation of its polyglutamate derivatives. Impaired membrane transport mediated by RFC is an established mechanism of intrinsic and acquired resistance to MTX (see below). In the absence of RFC function, the only way antifolate activity can be sustained is if drug can enter tumor cells by passive diffusion or by another transport route. However, to achieve the former for a hydrophilic drug or the latter via PCFT, which operates inefficiently at neutral $\mathrm{pH}$, requires very high drug levels with a high potential for toxicity to normal tissues. The membrane transport of folates and antifolates has been the subject of recent reviews $6,7,10,11$.

\section{High-dose MTX with "Leucovorin Rescue"}

With the recognition that MTX resistance in experimental tumor systems was often associated with impaired RFC-mediated transport across the cell membrane and with the assumption that delivery to cells within solid tumors is limited by a compromised vasculature, an approach was developed to circumvent these limitations that would permit the safe administration of very high doses of MTX ${ }^{32-35}$.

The rationale for high-dose MTX is that high blood and extracellular drug levels facilitate diffusion of drug into the core of solid tumors and passive diffusion across the tumor cell membrane, where carrier mediated transport might be compromised. Protection of normal tissues is achieved by the subsequent administration of low doses of 5- 
formyltetrahydrofolate (5-formylTHF; leucovorin) following treatment with MTX. Presumably, leucovorin has access to bone marrow and intestinal cells via an intact vascular supply to these normal tissues, and intact membrane transport, while delivery to tumor cells is limited by the low blood levels of the rescue agent, the compromised vascular supply, and impaired transport across the tumor cell membrane. Additionally, as the MTX blood level falls, leucovorin concentrations in the blood are sufficiently high to competitively inhibit MTX transport into normal cells via RFC, (a transport mechanism that MTX and leucovorin share), allowing the MRP exporters to pump the drug, unopposed, out of these cells. While high-dose MTX regimens were implemented in the 1960's, these regimens remain part of the treatment arsenal for several malignancies (see below).

A further understanding of the "selectivity" of high-dose MTX with "leucovorin rescue" emerged several decades after the introduction of this regimen and relates to the differential formation of MTX polyglutamate derivatives in tumors versus normal bone marrow and intestinal precursors ${ }^{19-22}$. This was based upon the revelation that polyglutamate derivatives of MTX are not only potent inhibitors of DHFR but also direct inhibitors of tetrahydrofolate-requiring enzymes: thymidylate synthase ${ }^{36}$, and one of the enzymes required for the synthesis of purines, 5-aminoimidazole-4-carboxamide ribotide transformylase (AICAR transformylase) ${ }^{37-39}$. These direct inhibitory effects block the utilization of the one-carbon moiety of leucovorin for thymidylate and purine synthesis in tumors; however, utilization is unimpeded in normal tissues that lack comparable levels of these derivatives ${ }^{40}$. An additional factor is interconversion of leucovorin to other tetrahydrofolate cofactors and ultimately to dihydrofolate polyglutamates that displace MTX from, and thereby activate, DHFR in cells which do not contain MTX polyglutamate derivatives ${ }^{41}$.

There are a variety of ways of administering high doses of MTX; these include pulses of drug, or continuous infusions for up to 42 hours, following which low-dose leucovorin is begun. Specific regimens of administration have been developed, and parameters designated, to assure the safety of these protocols based upon the expected renal excretion of MTX and decline in the MTX blood level. Any compromise of renal function and glomerular filtration, that can occur after high-dose MTX, delays clearance of drug and requires prolongation of leucovorin "rescue" until the MTX concentration in the blood falls to a safe level ${ }^{42,43}$.

\section{Current Clinical Applications of Methotrexate}

MTX remains an important agent for the treatment of acute leukemia, lymphoma, osteosarcoma, and leptomeningeal metastases ${ }^{44-46}$. MTX continues to be used for the treatment of gestational trophoblast tumors ${ }^{47}$ and in the cytoxan-MTX-fluorouracil (CMF) regimen for the treatment of breast cancer ${ }^{48,49}$. This drug is also widely used for the treatment of rheumatoid arthritis, inflammatory bowel disease, psoriasis, and other inflammatory diseases ${ }^{50-55}$. While introduced in the $1960 \mathrm{~s}{ }^{33,34}$, high-dose MTX regimens continue to have a role in the treatment of leukemia, lymphoma and osteosarcoma 46,56-58.

\section{The Emergence of a New-Generation 4-amino-antifolate - Pralatrexate}

As an understanding of the pharmacological properties of MTX emerged, and its interaction with intact cells that were key determinants of its cytotoxicity were identified, a search was undertaken to create a structural analog that would enhance its activity and its selectivity. The key parameters identified were membrane transport and polyglutamation. This led to the development of pralatrexate ${ }^{59,60}$. This antifolate differs from MTX in the substitution of a carbon for nitrogen at the $\mathrm{N}^{10}$ position and the substitution of a propargyl for the methyl group at that site (Figure 3). This drug has a much higher affinity for RFC and FPGS than 
MTX. This should lead to higher levels of the monoglutamate within cells, the substrate for FPGS and this, along with the much higher affinity for this enzyme, should result in a marked increase in the level of these active derivatives. It is unclear as to the level of pralatrexate polyglutamate derivatives that form within cells or the extent to which they, like MTX, are direct inhibitors of thymidylate synthase and AICAR transformylase. Likewise it not established, as yet, as to whether this drug can be administered safely within the context of a leucovorin "rescue" regimen.

Pralatrexate does appear to have enhanced "selectivity" since it can be administered at doses comparable to MTX, despite its enhanced properties that should lead to much higher levels in cells at comparable blood levels. The basis for this difference in selectivity is not clear. Pralatrexate appears to be active in T-cell but not B-cell leukemias and lymphomas; however, the basis for this difference has not been established. Pralatrexate is approved for treatment of cutaneous T-cell lymphoma with folate supplementation which moderates toxicity to this agent ${ }^{61-63}$. Considerable additional information will be required about the cellular and biochemical pharmacological properties of this drug before its full spectrum of clinical activities and utility can be achieved.

\section{The Emergence of Antifolates that have as their Target Tetrahydrofolate- requiring Enzymes}

\section{Raltitrexed}

The recognition that the polyglutamate derivatives of MTX have targets downstream of DHFR as direct inhibitors of thymidylate synthase and AICAR transformylase led to a drug development effort focused on the identification of antifolates which, in their polyglutamate forms, are direct inhibitors of one or both of these enzymes. The first of these agents to be established in the clinic was raltitrexed (Figure 3) ${ }^{64,65}$. In its polyglutamate forms, this drug has a high affinity for thymidylate synthase. It is also a much better substrate than MTX for FPGS with comparable affinity for RFC, the former required for inhibition of its target enzyme. Raltitrexed has a very low affinity for PCFT. This drug is utilized clinically primarily for the treatment of colorectal cancer in Europe and elsewhere; it is not approved for cancer treatment in the United States ${ }^{66-68}$.

\section{Pemetrexed}

The second inhibitor of tetrahydrofolate cofactor-requiring enzymes to enter the clinic and achieve approval was pemetrexed (Figure 3). In its polyglutamate forms, this drug is a potent inhibitor of thymidylate synthase. Initially it was considered to be an inhibitor of glycinamide ribonucleotide formyltransferase (GAR transformylase) which, like AICAR transformylase, is required for purine synthases ${ }^{69,70}$. However, recent studies indicates that the interruption of purine synthesis within cells is due to inhibition of AICAR transformylase (see below). Inhibition of thymidylate synthase occurs at extracellular levels of pemetrexed about $1 / 10^{\text {th }}$ the concentration required for inhibition of purine synthesis. This drug is an excellent substrate for FPGS, 300 times more potent than MTX, and has comparable affinity for RFC ${ }^{64}$. What is of particular interest is that pemetrexed has a much higher affinity than MTX for PCFT both at acidic and neutral $\mathrm{pH}^{5,28,71}$. The high affinity for PCFT, and delivery via this mechanism, results in the preservation of pemetrexed activity even when transport mediated by RFC is abolished. Hence, tumor cells resistant to raltitrexed or MTX due to impaired transport via RFC retain sensitivity to pemetrexed, a considerable advantage for this drug 28,72 .

Of recent particular interest is emerging data indicating that pemetrexed effects on purine synthesis in cells are due to suppression of AICAR transformylase resulting in the build-up 
of high cellular levels of ZMP that activate AMP kinase which, in turn, results in inhibition of mTOR 73,74 . Hence, an antimetabolite that, on the one hand, has potent cytotoxic activity through its inhibition of thymidylate synthase can also inhibit a major signal transduction pathway, which cumulatively results in cell growth inhibition and cell death.

Pemetrexed is currently approved for the first and second line treatment of the nonsquamous histology of non-small cell lung cancer and mesothelioma, in combination with cisplatin, and for maintenance therapy of lung cancer as a single agent ${ }^{75-78}$. The basis for the difference in activity between squamous and nonsquamous lung carcinomas is not clear. Ongoing clinical trials are evaluating pemetrexed efficacy in other malignancies. The development of pemetrexed and its cellular and biochemical properties is the subject of a recent review 5 .

\section{The Impact of Physiological Folates on the Antitumor Activities and Toxicity of Antifolates}

Drugs that require polyglutamation to achieve activity, in particular raltitrexed and pemetrexed, are generally sensitive to the level of physiological folates with cells which are substrates for FPGS and compete with these antifolates for this enzyme ${ }^{79}$. Hence, the higher the folate levels in tumor cells, the poorer the activity of these agents 80,81 . On the other hand, folate sufficiency is also an important element in toxicity to patients receiving these drugs; the most sensitive indicator of B12 or folate deficiency is reflected in an elevated blood homocysteine level ${ }^{75,82}$. To avoid this toxicity, folic acid and vitamin B12 are coadministered with pemetrexed and pralatrexate in clinical regimens $75,82,83$. The strategy here is to provide sufficient folate supplementation to protect patients from serious toxicity while not substantially impairing the activity of the drug against the tumor. Accordingly, folic acid supplementation should be used at the lowest recommended dose and frequency of administration.

\section{Mechanisms of Resistance to Antifolates}

Mechanisms of resistance to MTX have been established by studies in tumor systems in vitro under conditions in which selective pressure has been applied by gradual exposure to increasing concentrations, or pulse exposures to high concentrations, of drug. Chemical mutagenesis has also been used to accelerate and amplify mutational events contributing to resistance. All elements of the interaction of this drug with its cellular targets have been implicated in resistance. Membrane transport is a frequent mechanism of resistance due to low expression or loss-of-function mutations of RFC. Similar changes have been detected in human tissues as a basis for intrinsic or acquired resistance to MTX. Resistance has also developed due to loss-of-function mutations of FPGS resulting in impaired formation of MTX polyglutamate derivatives. Finally, DHFR mutations resulting in a decreased affinity for the drug, or increased expression of the enzyme, due to a regulatory change or amplification of the gene, result in resistance. The pattern of resistance to pralatrexate is not, as yet, known but is likely to be similar to that of MTX. The mechanisms of resistance to 4amino-antifolates has been the subject of recent reviews 16,84 .

Resistance to pemetrexed acquired in tumor lines in vitro correlates best with increased levels of thymidylate synthase ${ }^{85}$. Based upon studies on explanted human tumor specimens in vitro, low levels of thymidylate synthase, GAR transformylase and MRP4 gene expression were associated with increased sensitivity to pemetrexed ${ }^{86}$. On the other hand, decreased expression of FPGS would lead to impaired formation of the active pemetrexed polyglutamate derivatives ${ }^{87}$. Resistance to pemetrexed in human solid tumors due to impaired membrane transport has not been documented and is unlikely to occur since this 
drug can utilize both RFC and PCFT. Activity is retained with loss of the former due to transport mediated by PCFT and the accompanying contraction in tetrahydrofolate cofactor pools within the cells as a result of impaired uptake and accumulation of folates transported primarily by RFC $28,72,88$.

\section{Targeting Drugs to Tumor Cells via Folate Transporters}

A major emphasis of current drug-development efforts, in general, is directed to targeting pathways or regulatory elements that drive the proliferation of malignant cells. Another approach is the development cytotoxics and other agents that are selectively delivered to malignant cells via transporters that are selectively expressed, and/or selectively active, in malignant cells. These efforts have focused on two transporters - PCFT, and folate receptors.

\section{Folate receptor-targeted drugs}

There are two major folate receptor isotypes expressed on cell membranes with a binding constant for folic acid of 1-2 nM; the binding constant of the isolated protein is in the $\mathrm{pM}$ range. Folate receptor alpha (FRa) and folate receptor beta (FRß) both transport folates and antifolates by a receptor-mediated endocytosis ${ }^{89,90}$. FRa is broadly expressed in epithelial tumors ${ }^{91}$. Its expression in normal tissues is restricted to certain epithelia (apical membrane of proximal renal tubular cells, retinal pigment epithelium, choroid plexus). FR $\beta$ is expressed in spleen, thymus, late-stage myeloid cells but not CD34+ progenitors. It is highly expressed in hematopoietic malignancies ${ }^{90}$ and also expressed on activated and tumorassociated macrophages ${ }^{92}$. These folate receptors are a component of an endocytic process in which folates bind to the receptor following which the surrounding membrane invaginates, forms an endosomal vesicle that buds off within the cytoplasm to circulate within the endosomal compartment where the endosomal $\mathrm{pH}$ decreases. The folate is then released from the receptor and is exported from the endosome into the cytosol in a process mediated in part by PCFT.

This endocytic mechanism has now been harnessed for the delivery of anticancer drugs 9,90 . In the most advanced application, directed to FRa, drugs are linked to folic acid via a spacer and another segment containing a cleavable disulfide bond (Figure 7). The folic acid-drug complex binds to the receptor, is endocytosed, and when the reducing potential within the endosomes increases, the disulfide bond ruptures, drug is released from folic acid, and exits the endosome. A requirement is that the drug must be sufficiently lipid soluble to freely diffuse across the endosomal membrane so that it can be available to interact with its intracellular target(s). Another requirement is that the drug must be highly toxic since there are only a limited number of folate receptors on tumor cells with a limited capacity for delivery of drug.

The drug currently in clinical trials, that utilizes this technology, is folic acid linked to a highly potent vinca alkaloid, desacetylvinblastine ${ }^{93,94}$. The most advanced clinical trials to date have been focused on ovarian cancer which, among cancers, has the highest expression of FRa ${ }^{95,96}$. Another disease in which this agent is being evaluated is lung cancer, where expression of FRa is also prevalent. Complementing this therapeutic is a diagnostic reagent, folic acid linked to Technicium-99 which allows scanning patients to establish the expression and function of folate receptors in the tumor 97,98 . Hence, only patients that express functional FRa would be expected to benefit from the drug. The diagnostic reagent also allows re-evaluation of patients after they have failed one folic acid conjugate to determine whether the endocytic process remains intact. If that is the case, it would allow administration of another conjugate in which folic acid is linked to a different cytotoxic. Another application of this technology is the linkage of folic acid to a fluorescent molecule 
for visual localization of tumor in the intraoperative setting ${ }^{99}$. The status of these folic acid conjugates has been reviewed recently 8,9 .

Another class of drugs, in this case antifolates, is being developed that have high affinity for FRa but very low affinity for RFC which is the major route of delivery of antifolates to normal tissues. In this way the drug is delivered exclusively via FRa which is selectively expressed on tumors; there is very limited, or no, transport mediated by RFC, thereby protected bone marrow and intestinal cells that express this carrier. One such antifolate, ONYX0801 a thymidylate synthase inhibitor, is currently in clinical development for the treatment of solid tumors ${ }^{100}$.

In another approach, antifolates are being developed with high affinity for PCFT but low affinity for RFC 26,101,102. The strategy here, again, is to limit uptake into normal tissues via RFC. However, rather than targeting to folate receptors, the transport route targeted is PCFT. This transporter is widely expressed in solid tumors and, while also expressed in normal tissues, limited uptake is expected via this route under physiological conditions. Hence, the compromised blood supply in solid tumors, resulting in local hypoxia, along with the release of lactate due to the shift to anaerobic glycolysis inherent in malignant cells, should produce an acidic environment that favor PCFT-mediated transport ${ }^{103-105}$. On the other hand, PCFT-mediated transport should be negligible at the neutral $\mathrm{pH}$ of normal tissues with a physiological blood supply and intact aerobic metabolism

\section{References}

1. Skipper HE, Perry S. Kinetics of normal and leukemic leukocyte populations and relevance to chemotherapy. Cancer Res. 1970; 30:1883-97. [PubMed: 4917694]

2. Goldin A, Venditti JM, Humphreys SR, et al. A quantitative comparison of the antileukemic effectiveness of two folic acid antagonists in mice. J Natl Cancer Inst. 1955; 15:1657-64. [PubMed: 14381889]

3. Farber S, Diamond LK, Mercer RD, et al. Temporary remission in acute leukemia in children produced by folic acid antagonist, 4-aminopteroyl glutamic acid (aminopterin). N Engl J Med. 1948; 238:787-93. [PubMed: 18860765]

4. Goldman ID, Chattopadhyay S, Zhao R, et al. The Antifolates: Evolution, New Agents in the Clinic, and How targeting delivery via specific membrane transporters is driving the development of a next generation of folate analogs. Curr Opin Investig Drugs. 2010; 11:1409-23.

5. Chattopadhyay S, Moran RG, Goldman ID. Pemetrexed: biochemical and cellular pharmacology, mechanisms, and clinical applications. Mol Cancer Ther. 2007; 6:404-17. [PubMed: 17308042]

6. Zhao R, Matherly LH, Goldman ID. Membrane transporters and folate homeostasis: intestinal absorption and transport into systemic compartments and tissues. Expert Rev Mol Med. 2009; 11:e4. [PubMed: 19173758]

7. Matherly LH, Hou Z. Structure and Function of the Reduced Folate Carrier A Paradigm of a Major Facilitator Superfamily Mammalian Nutrient Transporter. Vitam Horm. 2008; 79C:145-84. [PubMed: 18804694]

8. Leamon CP, Jackman AL. Exploitation of the folate receptor in the management of cancer and inflammatory disease. Vitam Horm. 2008; 79:203-33. [PubMed: 18804696]

9. Xia W, Low PS. Folate-targeted therapies for cancer. J Med Chem. 2010; 53:6811-24. [PubMed: 20666486]

10. Zhao R, Diop-Bove N, Visentin M, et al. Mechanisms of Membrane Transport of Folates into Cells and Across Epithelia. Annu Rev Nutr. 2011; 31:177-201. [PubMed: 21568705]

11. Matherly LH, Hou Z, Deng Y. Human reduced folate carrier: translation of basic biology to cancer etiology and therapy. Cancer Metastasis Rev. 2007; 26:111-28. [PubMed: 17334909]

12. Qiu A, Jansen M, Sakaris A, et al. Identification of an intestinal folate transporter and the molecular basis for hereditary folate malabsorption. Cell. 2006; 127:917-28. [PubMed: 17129779] 
13. Stokstad, ELR. Historical perspective on key advances in the biochemistry and physiology of folates. In: Picciano, MF.; Stokstad, ELR., editors. Folic Acid Metabolism in Health and Disease. Wiley-Liss; New York: 1990. p. 1-21.

14. Fujii K, Nagasaki T, Huennekens FM. Accumulation of 5-methyltetrahydrofolate in cobalamindeficient L1210 mouse leukemia cells. J Biol Chem. 1982; 257:2144-6. [PubMed: 7061412]

15. Schramm VL. Enzymatic transition states, transition-state analogs, dynamics, thermodynamics, and lifetimes. Annu Rev Biochem. 2011; 80:703-32. [PubMed: 21675920]

16. Zhao R, Goldman ID. Resistance to antifolates. Oncogene. 2003; 22:7431-57. [PubMed: 14576850]

17. Lowe KE, Osborne CB, Lin B-F, et al. Regulation of folate and one-carbon metabolism in mammalian cells. II. Effect of folylpoly-gamma-glutamate synthetase substrate specificity and level on folate metabolism and folylpoly-gamma-glutamate specificity of metabolic cycles of onecarbon metabolism. J Biol Chem. 1993; 268:21665-73. [PubMed: 8408019]

18. Shane B. Folylpolyglutamate synthesis and role in the regulation of one-carbon metabolism. Vitam Horm. 1989; 45:263-335. [PubMed: 2688305]

19. Koizumi S, Ueno Y, Ohno I, et al. Reversal of methotrexate cytotoxicity to human bone marrow cells and leukemic K562 cells by leucovorin: methotrexate polyglutamates formation as a possible important factor. Jpn J Cancer Res. 1990; 81:1162-7. [PubMed: 1702414]

20. Poser RG, Sirotnak FM, Chello PL. Differential synthesis of methotrexate polyglutamates in normal proliferative and neoplastic mouse tissues in vivo. Cancer Res. 1981; 41:4441-6. [PubMed: 6171339]

21. Fry DW, Anderson LA, Borst M, et al. Analysis of the role of membrane transport and polyglutamylation of methotrexate in gut and Ehrlich tumor in vivo as factors in drug sensitivity and selectivity. Cancer Res. 1983; 43:1087-92. [PubMed: 6186369]

22. Fabre I, Fabre G, Goldman ID. Polyglutamylation, an important element in methotrexate cytotoxicity and selectivity in tumor versus murine granulocytic progenitor cells in vitro. Cancer Res. 1984; 44:3190-5. [PubMed: 6204743]

23. Zhao R, Min SH, Qiu A, et al. The spectrum of mutations in the PCFT gene, coding for an intestinal folate transporter, that are the basis for hereditary folate malabsorption. Blood. 2007; 110:1147-52. [PubMed: 17446347]

24. Mahadeo, KM.; Min, SH.; Diop-Bove, N.; Kronn, D.; Goldman, ID. Hereditary Folate Malabsorption. In: Pagon, RA.; Bird, TC.; Dolan, CR.; Stephens, K., editors. GeneReviews [Internet]. University of Washington, Seattle; Seattle,WA: 2010.

25. Zhao R, Gao F, Hanscom M, et al. A prominent low-pH methotrexate transport activity in human solid tumor cells: Contribution to the preservation of methotrexate pharmacological activity in HeLa cells lacking the reduced folate carrier. Clin Cancer Res. 2004; 10:718-27. [PubMed: 14760095]

26. Desmoulin SK, Wang L, Hales E, et al. Therapeutic Targeting of a Novel 6-substituted Pyrrolo[2,3-d]Pyrimidine Thienoyl Antifolate to Human Solid Tumors Based on Selective Uptake by the Proton-coupled Folate Transporter. Mol Pharmacol. 2011 [epub ahead of print].

27. Zhao R, Qiu A, Tsai E, et al. The proton-coupled folate transporter (PCFT): impact on pemetrexed transport and on antifolate activities as compared to the reduced folate carrier. Mol Pharmacol. 2008; 74:854-62. [PubMed: 18524888]

28. Zhao R, Hanscom M, Chattopadhyay S, et al. Selective preservation of pemetrexed pharmacological activity in HeLa cells lacking the reduced folate carrier; association with the presence of a secondary transport pathway. Cancer Res. 2004; 64:3313-9. [PubMed: 15126375]

29. Volk EL, Schneider E. Wild-type breast cancer resistance protein (BCRP/ABCG2) is a methotrexate polyglutamate transporter. Cancer Res. 2003; 63:5538-43. [PubMed: 14500392]

30. Kruh GD, Belinsky MG. The MRP family of drug efflux pumps. Oncogene. 2003; 22:7537-52. [PubMed: 14576857]

31. Assaraf YG. The role of multidrug resistance efflux transporters in antifolate resistance and folate homeostasis. Drug Resist Updat. 2006; 9:227-46. [PubMed: 17092765]

32. SCHOENBACH EB, GREENSPAN EM, COLSKY J. Reversal of aminopterin and amethopterin toxicity by citrovorum factor. J Am Med Assoc. 1950; 144:1558-60. [PubMed: 14794378] 
33. Djerassi I. Methotrexate infusions and intensive supportive care in the management of children with acute lymphocytic leukemia: follow-up report. Cancer Res. 1967; 27:2561-4. [PubMed: 5237351]

34. Hryniuk WM, Bertino JR. Treatment of leukemia with large doses of methotrexate and folinic acid: clinical-biochemical correlates. J Clin Invest. 1969; 48:2140-55. [PubMed: 5259150]

35. Pratt CB, Roberts D, Shanks EC, et al. Clinical trials and pharmacokinetics of intermittent highdose methotrexate-"leucovorin rescue" for children with malignant tumors. Cancer Res. 1974; 34:3326-31. [PubMed: 4547680]

36. Allegra CJ, Chabner BA, Drake JC, et al. Enhanced inhibition of thymidylate synthase by methotrexate polyglutamates. J Biol Chem. 1985; 260:9720-6. [PubMed: 2410416]

37. Allegra CJ, Drake JC, Jolivet J, et al. Inhibition of phosphoribosylaminoimidazolecarboxamide transformylase by methotrexate and dihydrofolic acid polyglutamates. Proc Natl Acad Sci U S A. 1985; 82:4881-5. [PubMed: 3860829]

38. Allegra CJ, Fine RL, Drake JC, et al. The effect of methotrexate on intracellular folate pools in human MCF-7 breast cancer cells. Evidence for direct inhibition of purine synthesis. J Biol Chem. 1986; 261:6478-85. [PubMed: 3700401]

39. Baggott JE, Vaughn WH, Hudson BB. Inhibition of 5-aminoimidazole-4-carboxamide ribotide transformylase, adenosine deaminase and 5 -adenylate deaminase by polyglutamates of methotrexate and oxidized folates and by 5-aminoimidazole-4-carboxamide riboside and ribotide. Biochem J. 1986; 236:193-200. [PubMed: 2431676]

40. Matherly LH, Barlowe CK, Phillips VM, et al. The effects of 4-aminoantifolates on 5formyltetrahydrofolate metabolism in L1210 cells. J Biol Chem. 1987; 262:710-7. [PubMed: 2948949]

41. Matherly LH, Barlowe CK, Goldman ID. Antifolate polyglutamylation and competitive drug displacement at dihydrofolate reductase as important elements in leucovorin rescue in L1210 cells. Cancer Res. 1986; 46:588-93. [PubMed: 2416428]

42. Treon SP, Chabner BA. Concepts in use of high-dose methotrexate therapy. Clin Chem. 1996; 42:1322-9. [PubMed: 8697606]

43. Widemann BC, Adamson PC. Understanding and managing methotrexate nephrotoxicity. Oncologist. 2006; 11:694-703. [PubMed: 16794248]

44. Gaynon PS, Angiolillo AL, Carroll WL, et al. Long-term results of the children's cancer group studies for childhood acute lymphoblastic leukemia 1983-2002: a Children's Oncology Group Report. Leukemia. 2010; 24:285-97. [PubMed: 20016531]

45. Chamberlain MC. Leptomeningeal metastasis. Semin Neurol. 2010; 30:236-44. [PubMed: 20577930]

46. Jaffe N. Osteosarcoma: review of the past, impact on the future. The American experience. Cancer Treat Res. 2009; 152:239-62. [PubMed: 20213394]

47. Savage P, Seckl M, Short D. Practical issues in the management of low-risk gestational trophoblast tumors. J Reprod Med. 2008; 53:774-80. [PubMed: 19004403]

48. Colleoni M, Cole BF, Viale G, et al. Classical cyclophosphamide, methotrexate, and fluorouracil chemotherapy is more effective in triple-negative, node-negative breast cancer: results from two randomized trials of adjuvant chemoendocrine therapy for node-negative breast cancer. J Clin Oncol. 2010; 28:2966-73. [PubMed: 20458051]

49. Gennari A, Sormani MP, Pronzato P, et al. HER2 status and efficacy of adjuvant anthracyclines in early breast cancer: a pooled analysis of randomized trials. J Natl Cancer Inst. 2008; 100:14-20. [PubMed: 18159072]

50. Salliot C, van der HD. Long-term safety of methotrexate monotherapy in patients with rheumatoid arthritis: a systematic literature research. Ann Rheum Dis. 2009; 68:1100-4. [PubMed: 19060002]

51. Schwartz D, Ferguson JR. Current pharmacologic treatment paradigms for inflammatory bowel disease and the potential role of granulocyte/monocyte apheresis. Curr Med Res Opin. 2007; 23:2715-28. [PubMed: 17894921]

52. Braus NA, Elliott DE. Advances in the pathogenesis and treatment of IBD. Clin Immunol. 2009; 132:1-9. [PubMed: 19321388] 
53. Kalb RE, Strober B, Weinstein G, et al. Methotrexate and psoriasis: 2009 National Psoriasis Foundation Consensus Conference. J Am Acad Dermatol. 2009; 60:824-37. [PubMed: 19389524]

54. Chen M, Kallenberg CG. ANCA-associated vasculitides--advances in pathogenesis and treatment. Nat Rev Rheumatol. 2010; 6:653-64. [PubMed: 20924413]

55. Sharaf PH, Yazici Y. Necrotizing vasculitis--a 2009 update. Bull NYU Hosp Jt Dis. 2009; 67:3035. [PubMed: 19852754]

56. Matloub Y, Bostrom BC, Hunger SP, et al. Escalating intravenous methotrexate improves eventfree survival in children with standard-risk acute lymphoblastic leukemia: a report from the Children's Oncology Group. Blood. 2011; 118:243-51. [PubMed: 21562038]

57. Abramson JS, Hellmann M, Barnes JA, et al. Intravenous methotrexate as central nervous system (CNS) prophylaxis is associated with a low risk of CNS recurrence in high-risk patients with diffuse large B-cell lymphoma. Cancer. 2010; 116:4283-90. [PubMed: 20564149]

58. Asselin BL, Devidas M, Wang C, et al. Effectiveness of high-dose methotrexate in T-cell lymphoblastic leukemia and advanced-stage lymphoblastic lymphoma: a randomized study by the Children's Oncology Group (POG 9404). Blood. 2011; 118:874-83. [PubMed: 21474675]

59. DeGraw JI, Colwell WT, Piper JR, et al. Synthesis and antitumor activity of 10-propargyl-10deazaaminopterin. J Med Chem. 1993; 36:2228-31. [PubMed: 8340923]

60. Krug LM, Ng KK, Kris MG, et al. Phase I and pharmacokinetic study of 10-propargyl-10deazaaminopterin, a new antifolate. Clin Cancer Res. 2000; 6:3493-8. [PubMed: 10999734]

61. Wang ES, O'Connor O, She Y, et al. Activity of a novel anti-folate (PDX, 10-propargyl 10deazaaminopterin) against human lymphoma is superior to methotrexate and correlates with tumor RFC-1 gene expression. Leuk Lymphoma. 2003; 44:1027-35. [PubMed: 12854905]

62. O'Connor OA, Horwitz S, Hamlin P, et al. Phase II-I-II study of two different doses and schedules of pralatrexate, a high-affinity substrate for the reduced folate carrier, in patients with relapsed or refractory lymphoma reveals marked activity in T-cell malignancies. J Clin Oncol. 2009; 27:435764. [PubMed: 19652067]

63. O'Connor OA, Hamlin PA, Portlock C, et al. Pralatrexate, a novel class of antifol with high affinity for the reduced folate carrier-type 1, produces marked complete and durable remissions in a diversity of chemotherapy refractory cases of T-cell lymphoma. Br J Haematol. 2007; 139:4258. [PubMed: 17910632]

64. Habeck LL, Mendelsohn LG, Shih C, et al. Substrate specificity of mammalian folylpolyglutamate synthetase for 5,10-dideazatetrahydrofolate analogs. Mol Pharmacol. 1995; 48:326-33. [PubMed: 7651366]

65. Jackman AL, Taylor GA, Gibson W, et al. ICI D1694, a quinazoline antifolate thymidylate synthase inhibitor that is a potent inhibitor of L1210 tumor cell growth in vitro and in vivo: A new agent for clinical study. Cancer Res. 1991; 51:5579-86. [PubMed: 1913676]

66. Cocconi G, Cunningham D, Van Cutsem E, et al. Open, randomized, multicenter trial of raltitrexed versus fluorouracil plus high-dose leucovorin in patients with advanced colorectal cancer. Tomudex Colorectal Cancer Study Group. J Clin Oncol. 1998; 16:2943-52. [PubMed: 9738562]

67. Popov I, Carrato A, Sobrero A, et al. Raltitrexed (Tomudex) versus standard leucovorin-modulated bolus 5-fluorouracil: Results from the randomised phase III Pan-European Trial in Adjuvant Colon Cancer 01 (PETACC-1). Eur J Cancer. 2008; 44:2204-11. [PubMed: 18707870]

68. Kempin S, Gutierrez J, Wilson E, et al. Raltitrexed (Tomudex): an alternative choice in patients intolerant to 5-fluorouracil. Cancer Invest. 2002; 20:992-5. [PubMed: 12449732]

69. Shih C, Chen VJ, Gossett LS, et al. LY231514, a pyrrolo[2,3-d]pyrimidine-based antifolate that inhibits multiple folate-requiring enzymes. Cancer Res. 1997; 57:1116-23. [PubMed: 9067281]

70. Taylor EC, Kuhnt D, Shih C, et al. A dideazatetrahydrofolate analogue lacking a chiral center at C-6, $N$-[4-[2-(2-amino-3,4-dihydro-4-oxo-7 H-pyrrolo[2, 3- $d$ ]pyrimidin-5-yl)ethyl]benzoyl]-Lglutamic acid, is an inhibitor of thymidylate synthase. J Med Chem. 1992; 35:4450-4. [PubMed: 1447744]

71. Wang Y, Zhao R, Goldman ID. Characterization of a folate transporter in HeLa cells with a low $\mathrm{pH}$ optimum and high affinity for pemetrexed distinct from the reduced folate carrier. Clin Cancer Res. 2004; 10:6256-64. [PubMed: 15448015] 
72. Chattopadhyay S, Zhao R, Krupenko SA, et al. The inverse relationship between reduced folate carrier function and pemetrexed activity in a human colon cancer cell line. Mol Cancer Ther. 2006; 5:438-49. [PubMed: 16505119]

73. Racanelli AC, Rothbart SB, Heyer CL, et al. Therapeutics by cytotoxic metabolite accumulation: pemetrexed causes ZMP accumulation, AMPK activation, and mammalian target of rapamycin inhibition. Cancer Res. 2009; 69:5467-74. [PubMed: 19549896]

74. Rothbart SB, Racanelli AC, Moran RG. Pemetrexed indirectly activates the metabolic kinase AMPK in human carcinomas. Cancer Res. 2010; 70:10299-309. [PubMed: 21159649]

75. Vogelzang NJ, Rusthoven JJ, Symanowski J, et al. Phase III Study of Pemetrexed in Combination With Cisplatin Versus Cisplatin Alone in Patients With Malignant Pleural Mesothelioma. J Clin Oncol. 2003; 21:2636-44. [PubMed: 12860938]

76. Hanna N, Shepherd FA, Fossella FV, et al. Randomized Phase III Trial of Pemetrexed Versus Docetaxel in Patients With Non-Small-Cell Lung Cancer Previously Treated With Chemotherapy. J Clin Oncol. 2004; 22:1589-97. [PubMed: 15117980]

77. Scagliotti GV, Parikh P, Von Pawel J, et al. Phase III study comparing cisplatin plus gemcitabine with cisplatin plus pemetrexed in chemotherapy-naive patients with advanced-stage non-small-cell lung cancer. J Clin Oncol. 2008; 26:3543-51. [PubMed: 18506025]

78. Ciuleanu T, Brodowicz T, Zielinski C, et al. Maintenance pemetrexed plus best supportive care versus placebo plus best supportive care for non-small-cell lung cancer: a randomised, doubleblind, phase 3 study. Lancet. 2009; 374:1432-40. [PubMed: 19767093]

79. Andreassi JL, Moran RG. Mouse folylpoly-gamma-glutamate synthetase isoforms respond differently to feedback inhibition by folylpolyglutamate cofactors. Biochemistry. 2002; 41:22635. [PubMed: 11772020]

80. Zhao R, Gao F, Goldman ID. Marked suppression of the activity of some, but not all, antifolate compounds by augmentation of folate cofactor pools within tumor cells. Biochem Pharmacol. 2001; 61:857-65. [PubMed: 11274972]

81. Chattopadhyay S, Tamari R, Min SH, et al. Commentary: a case for minimizing folate supplementation in clinical regimens with pemetrexed based on the marked sensitivity of the drug to folate availability. Oncologist. 2007; 12:808-15. [PubMed: 17673612]

82. Niyikiza C, Baker SD, Seitz DE, et al. Homocysteine and methylmalonic acid: markers to predict and avoid toxicity from pemetrexed therapy. Mol Cancer Ther. 2002; 1:545-52. [PubMed: 12479273]

83. Scagliotti GV, Shin DM, Kindler HL, et al. Phase II study of pemetrexed with and without folic acid and vitamin B12 as front-line therapy in malignant pleural mesothelioma. J Clin Oncol. 2003; 21:1556-61. [PubMed: 12697881]

84. Assaraf YG. Molecular basis of antifolate resistance. Cancer Metastasis Rev. 2007; 26:153-81. [PubMed: 17333344]

85. Zhang D, Ochi N, Takigawa N, et al. Establishment of pemetrexed-resistant non-small cell lung cancer cell lines. Cancer Lett. 2011; 309:228-35. [PubMed: 21742432]

86. Hanauske AR, Eismann U, Oberschmidt O, et al. In vitro chemosensitivity of freshly explanted tumor cells to pemetrexed is correlated with target gene expression. Invest New Drugs. 2007; 25:417-23. [PubMed: 17534577]

87. Mauritz R, Peters GJ, Priest DG, et al. Multiple mechanisms of resistance to methotrexate and novel antifolates in human CCRF-CEM leukemia cells and their implications for folate homeostasis. Biochem Pharmacol. 2002; 63:105-15. [PubMed: 11841783]

88. Zhao R, Zhang S, Hanscom M, et al. Loss of reduced folate carrier function and folate depletion result in enhanced pemetrexed inhibition of purine synthesis. Clin Cancer Res. 2005; 11:1294301. [PubMed: 15709201]

89. Kamen BA, Smith AK. A review of folate receptor alpha cycling and 5-methyltetrahydrofolate accumulation with an emphasis on cell models in vitro. Adv Drug Deliv Rev. 2004; 56:1085-97. [PubMed: 15094208]

90. Salazar MD, Ratnam M. The folate receptor: what does it promise in tissue-targeted therapeutics? Cancer Metastasis Rev. 2007; 26:141-52. [PubMed: 17333345] 
91. Parker N, Turk MJ, Westrick E, et al. Folate receptor expression in carcinomas and normal tissues determined by a quantitative radioligand binding assay. Anal Biochem. 2005; 338:284-93. [PubMed: 15745749]

92. Puig-Kroger A, Sierra-Filardi E, Dominguez-Soto A, et al. Folate receptor beta is expressed by tumor-associated macrophages and constitutes a marker for M2 anti-inflammatory/regulatory macrophages. Cancer Res. 2009; 69:9395-403. [PubMed: 19951991]

93. Reddy JA, Dorton R, Westrick E, et al. Preclinical evaluation of EC145, a folate-vinca alkaloid conjugate. Cancer Res. 2007; 67:4434-42. [PubMed: 17483358]

94. Leamon CP, Reddy JA, Vlahov IR, et al. Preclinical antitumor activity of a novel folate-targeted dual drug conjugate. Mol Pharm. 2007; 4:659-67. [PubMed: 17874843]

95. Li J, Sausville EA, Klein PJ, et al. Clinical pharmacokinetics and exposure-toxicity relationship of a folate-Vinca alkaloid conjugate EC145 in cancer patients. J Clin Pharmacol. 2009; 49:1467-76. [PubMed: 19837906]

96. Dosio F, Milla P, Cattel L. EC-145, a folate-targeted Vinca alkaloid conjugate for the potential treatment of folate receptor-expressing cancers. Curr Opin Investig Drugs. 2010; 11:1424-33.

97. Fisher RE, Siegel BA, Edell SL, et al. Exploratory study of 99mTc-EC20 imaging for identifying patients with folate receptor-positive solid tumors. J Nucl Med. 2008; 49:899-906. [PubMed: 18483093]

98. Reddy JA, Xu LC, Parker N, et al. Preclinical evaluation of (99m)Tc-EC20 for imaging folate receptor-positive tumors. J Nucl Med. 2004; 45:857-66. [PubMed: 15136637]

99. van Dam GM, Themelis G, Crane LM, et al. Intraoperative tumor-specific fluorescence imaging in ovarian cancer by folate receptor-alpha targeting: first in-human results. Nat Med. 2011; 17:13159. [PubMed: 21926976]

100. Gibbs DD, Theti DS, Wood N, et al. BGC 945, a novel tumor-selective thymidylate synthase inhibitor targeted to alpha-folate receptor-overexpressing tumors. Cancer Res. 2005; 65:11721-8. [PubMed: 16357184]

101. Desmoulin SK, Wang Y, Wu J, et al. Targeting the proton-coupled folate transporter for selective delivery of 6-substituted pyrrolo[2,3-d]pyrimidine antifolate inhibitors of de novo purine biosynthesis in the chemotherapy of solid tumors. Mol Pharmacol. 2010; 78:577-87. [PubMed: 20601456]

102. Wang L, Desmoulin SK, Cherian C, et al. Synthesis, Biological, and Antitumor Activity of a Highly Potent 6-Substituted Pyrrolo[2,3-d]pyrimidine Thienoyl Antifolate Inhibitor with ProtonCoupled Folate Transporter and Folate Receptor Selectivity over the Reduced Folate Carrier That Inhibits beta-Glycinamide Ribonucleotide Formyltransferase. J Med Chem. 2011; 54:7150-64. [PubMed: 21879757]

103. Helmlinger G, Yuan F, Dellian M, et al. Interstitial $\mathrm{pH}$ and $\mathrm{pO} 2$ gradients in solid tumors in vivo: high-resolution measurements reveal a lack of correlation. Nat Med. 1997; 3:177-82. [PubMed: 9018236]

104. Stubbs M, Rodrigues L, Howe FA, et al. Metabolic consequences of a reversed $\mathrm{pH}$ gradient in rat tumors. Cancer Res. 1994; 54:4011-6. [PubMed: 8033132]

105. Raghunand N, Altbach MI, van Sluis R, et al. Plasmalemmal pH-gradients in drug-sensitive and drug-resistant MCF-7 human breast carcinoma xenografts measured by 31P magnetic resonance spectroscopy. Biochem Pharmacol. 1999; 57:309-12. [PubMed: 9890558] 
Antifolates disrupt cellular proliferation by blocking folate-dependent one-carbon biosynthetic and methylation reactions

Antifolates form active polyglutamate derivatives that are retained in tumor cells and result in sustained inhibition of their target enzymes

Antifolates currently approved for cancer treatment include methotrexate and pralatrexated, inhibitors of dihydrofolate reductase, and pemetrexed that, in it polyglutamate forms, targets thymidylate synthase and AICARFT(5-aminoimidazole-4carboxamide ribonucleotide transformylase).

Novel folate analogs and conjugates, currently in clinical trial, utilize membrane folate receptors for transport into tumor cells by an endocytic mechanism. 


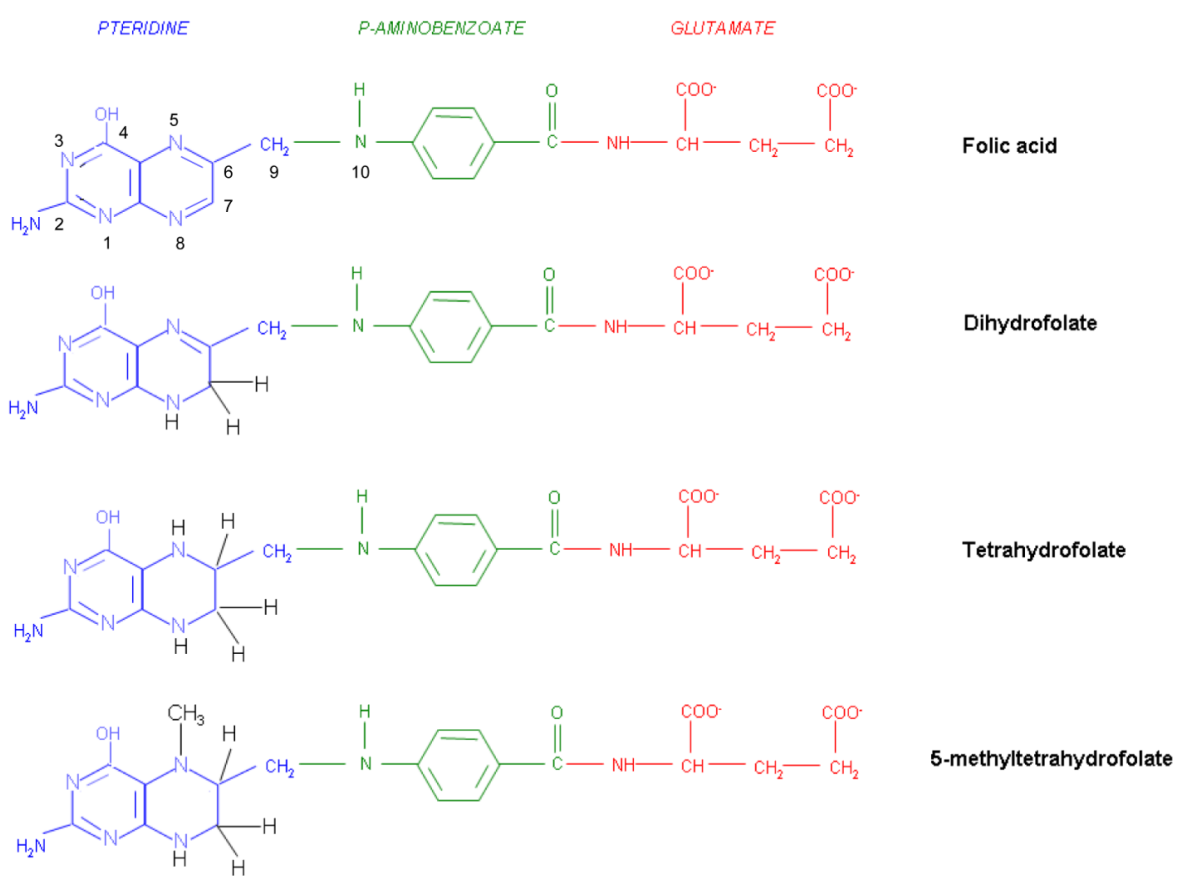

Figure 1.

The structures of folic acid, dihydrofolate, tetrahydrofolate, and 5-methyltetrahydrofolate. Folic acid is not a physiological folate but is an important source of folate in foods and vitamins. Within cells folic acid is reduced to dihydrofolate by dihydrofolate reductase (DHFR-see Figure 2), albeit at a very slow rate since it is a very poor substrate for this enzyme. Dihydrofolate is the major oxidized form of folates within cells, and the preferred substrate for DHFR, mediating the formation of tetrahydrofolate that goes on to form a variety of tetrahydrofolate cofactors. Seen here is the major dietary folate, and the major folate in the blood, 5-methyltetrahydrofolate. 


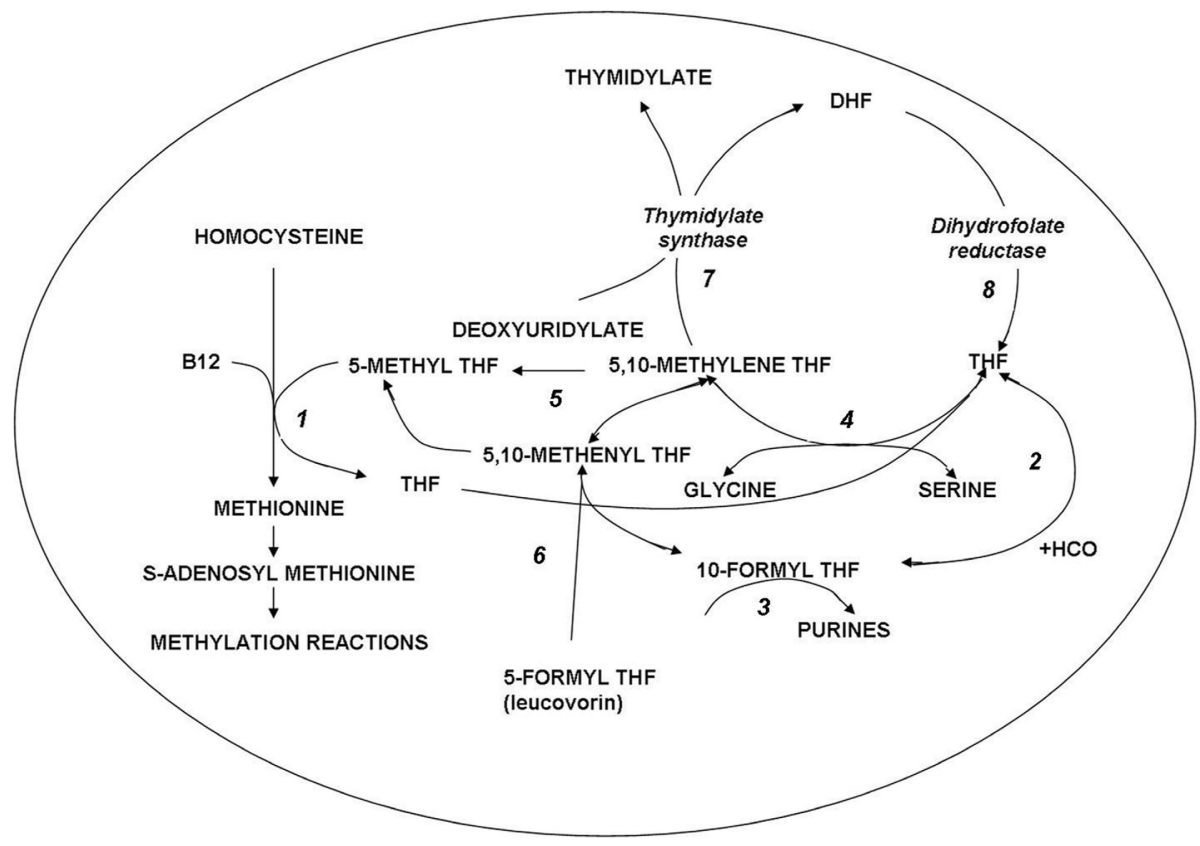

Figure 2.

Folate-dependent reactions within cells. Reaction1: 5-methyltetrahydrofolate (5-methylTHF) enters the folate cycle with the provision of its methyl group to homocysteine in the synthesis of methionine, a vitamin B12 dependent reaction mediated by methionine synthase. The tetrahydrofolate (THF) moiety can then acquire a carbon at various oxidation states. Reaction 2: Formate is added at the $\mathrm{N}^{10}$ position to form 10-formylTHF which provides two carbons in Reaction 3 for the synthesis of purines. Reaction 4: 5,10methyleneTHF is formed from serine and THF in a reaction mediated by serine hydroxyl methyltransferase. Reaction 5: 5-10-methyleneTHF is reduced irreversibly to 5-methylTHF. Reaction 6: 5-formytetrahydrofolate dehydrase is the mechanism by which 5-formylTHF (leucovorin) enters these cyclical folate pathways. Reaction 7: The formation of thymidylate mediated by thymidylate synthase; the THF moiety is oxidized to dihydrofolate (DHF).

Reaction 8: DHF is reduced to THF by dihydrofolate reductase. The latter is essential for maintaining THF cofactor pools within mammalian cells. 
<smiles>Nc1nc(O)c2nc(CNc3ccc(C(=O)NC(CCC(=O)O)C(=O)O)cc3)cnc2n1</smiles><smiles></smiles><smiles>Nc1nc(N)c2nc(CNc3ccc(C(=O)NC(CCC(=O)O)C(=O)O)cc3)cnc2n1</smiles><smiles>Nc1nc2[nH]cc(CCc3ccc(C(=O)NC(CCC(=O)O)C(=O)O)cc3)c2c(=O)[nH]1</smiles><smiles>CCOCCNC(CCC(=O)O)C(=O)O</smiles><smiles>C#CCC(Cc1cnc2nc(N)nc(N)c2n1)c1ccc(C(=O)NC(CCC(=O)O)C(=O)O)cc1</smiles>

Figure 3.

The structures of folic acid and a group of antifolates; except for aminopterin, all are in clinical use in the United States and/or elsewhere. 


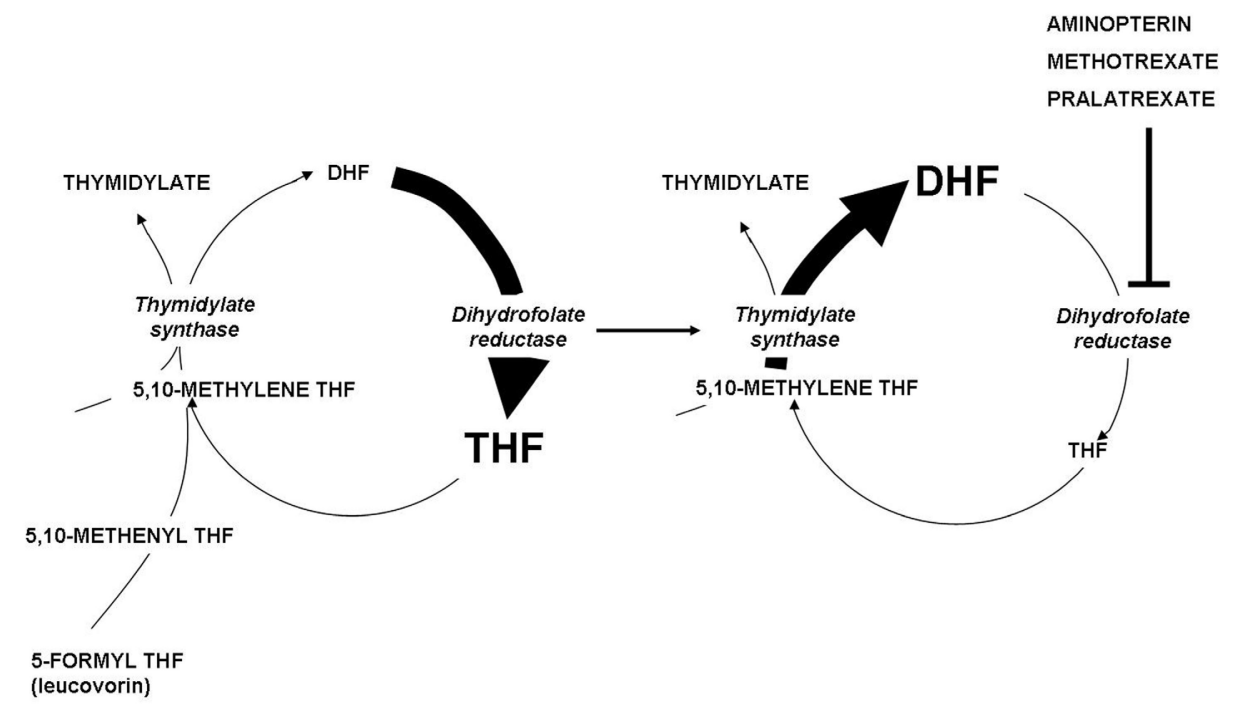

\section{Figure 4.}

The impact of dihydrofolate reductase inhibitors on folate pools within cells. The left panel illustrates that under physiological conditions dihydrofolate (DHF) produced during the synthesis of thymidylate mediated by thymidylate synthase is reduced to tetrahydrofolate (THF) so rapidly due to the high levels of dihydrofolate reductase (DHFR) within cells that the DHF level is trivial compared to the level of tetrahydrofolate. The right panel illustrates the impact of suppression of DHFR by several 4-amino antifolates. High levels of DHF build up in cells by continued thymidylate synthase activity, interconversion of THF cofactors to 5,10-methyleneTHF and oxidation to DHF. This leads to depletion of THF cofactor levels within cells and cessation of THF cofactor-dependent reactions. High DHF levels compete with MTX for the small percentage of enzyme sufficient to maintain THF cofactor pools within cells. 


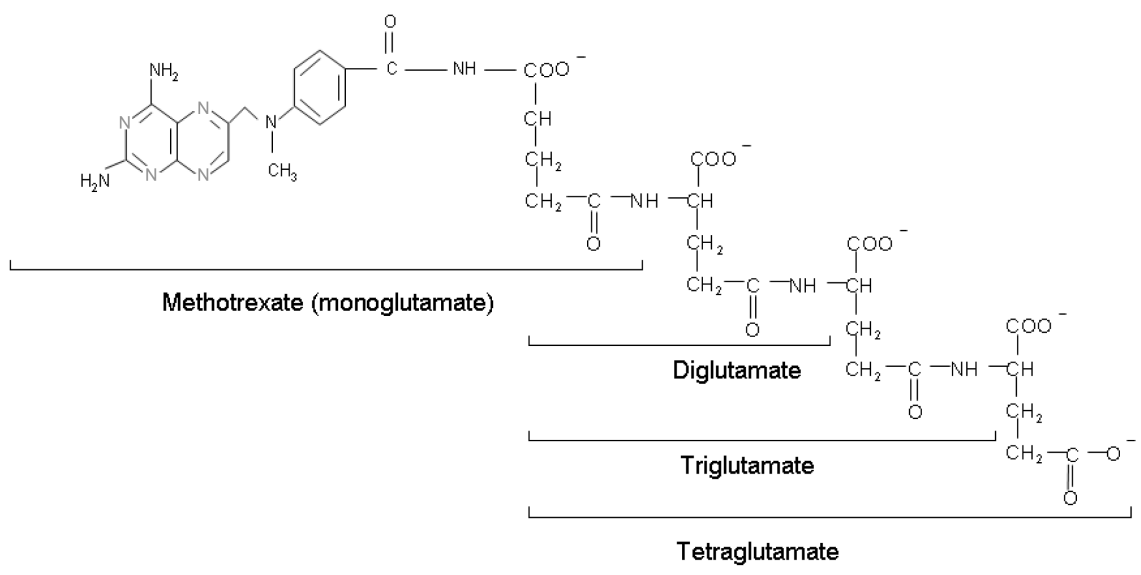

Figure 5.

The structure of the polyglutamate derivatives of MTX. Glutamates are progressively added to the $\mathrm{Y}$-carboxyl of the MTX molecule and each successive polyglutamate derivative. 


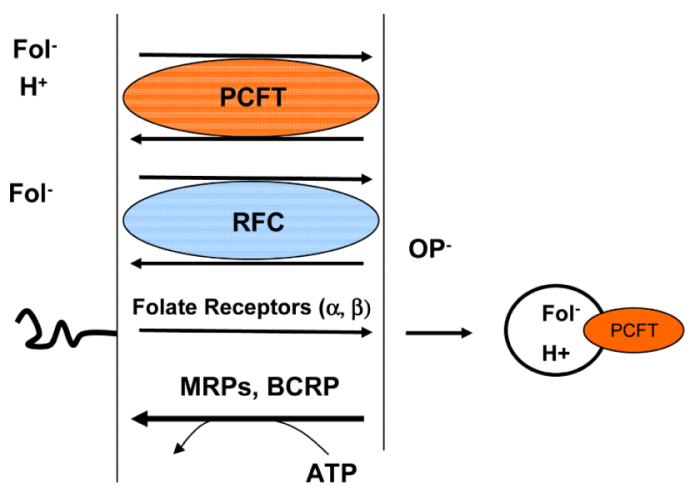

EXTRACELLULAR

INTRACELLULAR

Figure 6.

Folate-specific transport routes in mammalian cells. There are two carrier mechanisms: the reduced folate carrier (RFC), an organic phosphate $\left(\mathrm{OP}^{-}\right)$antiporter, and the proton-coupled folate transporter (PCFT), a proton-folate symporter. Both carriers transport folates and antifolates into cells against an electrochemical-potential gradient. Multidrug resistanceassociated proteins (MRPs) and the breast cancer resistance protein (BCRP) utilize the energy released in the hydrolysis of ATP to pump folate and antifolate monoglutamates out of cells. BCRP and some MRPs can export lower polyglutamates as well. Folate receptors transport folates into cells by an endocytic mechanism. Folate export from acidified endosomes is mediated, in part, by PCFT. 


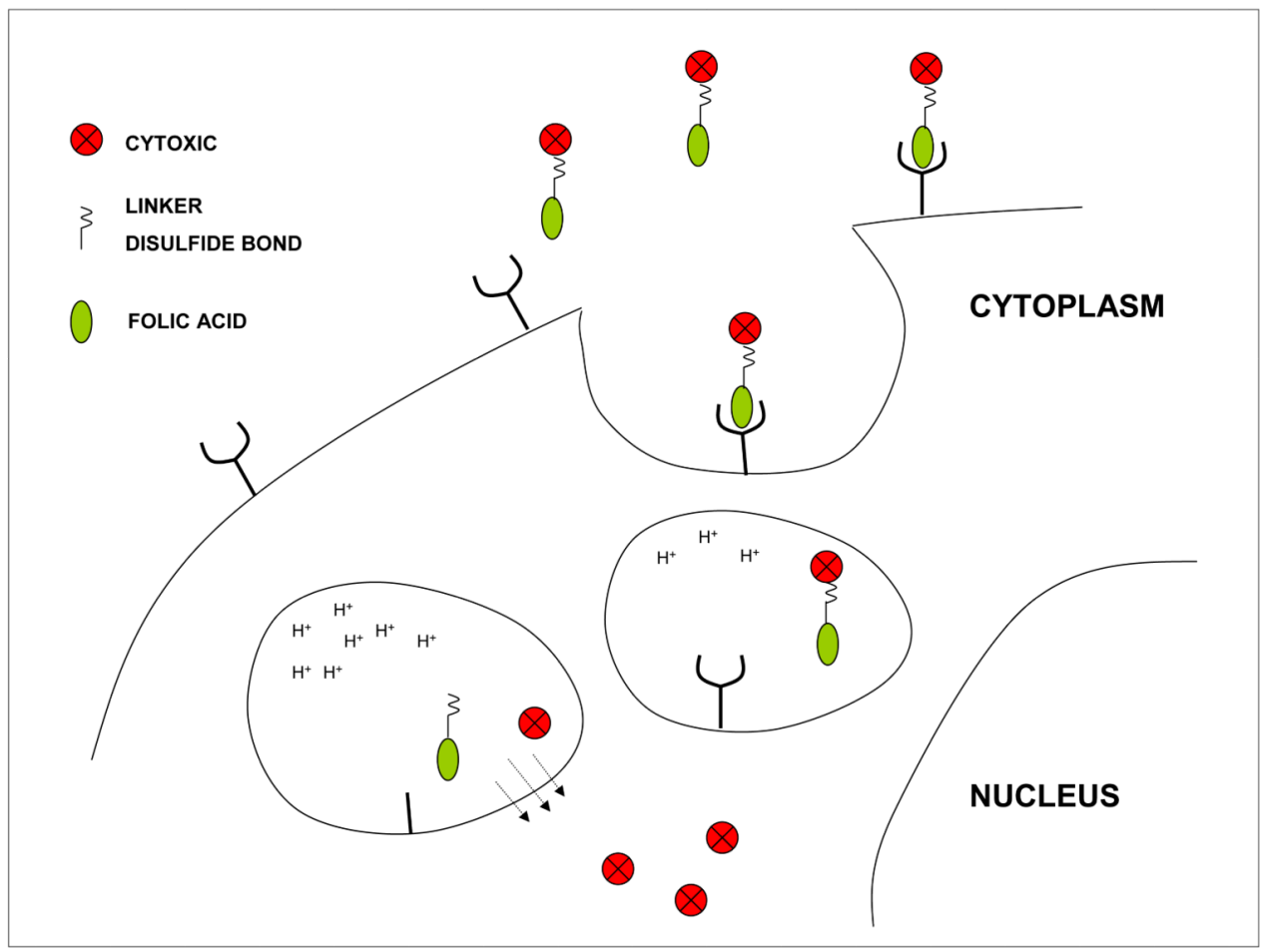

Figure 7.

Receptor mediated endocytosis of folic acid linked to cytotoxic agents. A drug is coupled to folic acid via a hydrophilic linker molecule and a segment containing a cleavable disulfide bond. The complex binds to the folate receptor at the cell membrane which invaginates and forms a vesicle that circulates within the endosomal compartment. As the vesicle matures the reducing potential increases, rupturing the disulfide bond releasing the cytotoxic which diffuses out of the endosome to reach its intracellular target. Folic acid can also be linked to Technicium-99 to establish the presence of folate receptors and the competence of the endocytic mechanism before treatment with the cytotoxic conjugate. 